\title{
PEMBIAYAAN BPR SYARIAH DALAM PENINGKATAN KESEJAHTERAAN UMKM : BEDASARKAN MAQASHID SHARIA
}

\author{
Debby Pramana \\ Ilmu Ekonomi , Fakultas Ekonomi, Universitas Negeri Surabaya \\ Rachma Indrarini \\ Ilmu Ekonomi , Fakultas Ekonomi, Universitas Negeri Surabaya \\ Email: rachmaindrarini@unesa.ac.id
}

\section{ARTICLE HISTORY \\ Received : \\ 04 January 2017 \\ Accepted :}

16 June 2017

Online Available :

30 June 2017

Keywords:

Finance, SME, Maqashid sharia

Kata Kunci :

Pembiayaan, UMKM, Maqashid syariah

\section{ABSTRACT}

Increased labor force population in Indonesia makes job seekers growing up. But the comparison between the labor force with jobs available showed greater workforce, causing unemployment. When an individual is unemployed then the individual as a whole can not meet their needs which result in decreased welfare. One way of overcoming the problem of unemployment is to encourage the community to entrepreneurship and provide financing to MSME (Micro, Small and Medium Enterprises. The financing of the SMEs can improve their welfare. This research is a descriptive qualitative research that examines the BPRS In Welfare Improvement Financing SME with the welfare indicators are maqashid sharia (Religion, Soul, Mind, Descendants and treasure). The result of this research is the increasing prosperity of SME customers after obtaining financing from the SRB.

ABSTRAK
Meningkatnya populasi angkatan kerja di Indonesia menjadikan
pencari kerja terus bertambah. Akan tetapi perbandingan antara
angkatan kerja dengan lapangan pekerjaan yang tersedia menunjukan
lebih besarnya angkatan kerja sehingga terjadi pengangguran. Ketika
seorang individu menganggur maka individu tersebut tidak bisa secara
keseluruhan memenuhi kebutuhan hidupnya yang berakibat
menurunnya kesejahteraan. Salah satu cara penanggulangan masalah
pengangguran adalah mendorong masayarakat untuk berwirausaha
dan memberikan pembiayaan pada UMKM (Usaha Mikro Kecil
Menengah). Diharapkan dengan adanya pembiayaan maka UMKM
dapat meningkatkan kesejahteraannya. Penelitian ini merupakan
penelitian kualitatif deskriptif yang meneliti Pembiayaan BPRS Dalam
Peningkatan Kesejahteraan UMKM dengan indikator kesejahteraan
adalah maqashid syariah (Agama, Jiwa, Akal, Keturunan dan Harta).
Hasil penelitian ini adalah adanya peningkatan kesejahteraan pada
nasabah UMKM setelah mendapatkan pembiayaan dari BPRS.




\section{PENDAHULUAN}

Meningkatnya populasi angkatan kerja di Indonesia menjadikan pencari kerja terus bertambah. Akan tetapi perbandingan antara angkatan kerja dengan lapangan pekerjaan yang tersedia menunjukan lebih besarnya angkatan kerja dibandingkan lapangan pekerjaan. Fenomena tersebut menjadikan meningkatnya jumlah pengangguran. Ketika seorang individu menganggur maka individu tersebut tidak bisa secara keseluruhan memenuhi kebutuhan hidupnya yang berakibat menurunnya kesejahteraan.

Salah satu masalah dalam perekonomian suatu Negara adalah tingginya jumlah pengangguran dan pemerintah harus dapat mengatasi permasalahan tersebut. Terdapat beberapa kebijakan fiskal yang digunakan oleh pemerintah dalam mengatasi pengangguran yakni menurunkan pajak, menambah pembelanjaan pemerintah, mendorong dan memberikan pembiayaan pada masyarakat untuk berwirausaha dengan mendirikan UMKM (Usaha Mikro Kecil Menengah) dan lain sebagainya. Diharapkan dengan banyaknya UMKM yang berkembang di Indonesia dapat mengurangi jumlah pengangguran sehingga dapat meningkatkan kesejahteraan individu dan pada jangka panjang dapat meningkatkan GDP (Gros Domestic Product) Indonesia sehingga dapat meningkatkan pertumbuhan ekonomi.

Usaha Mikro Kecil Menengah (UMKM) merupakan pelaku usaha dengan jumlah yang sangat besar, bahkan mayoritas dalam struktur pelaku usaha di tanah air. UMKM juga merupakan bagian integral dari roda kegiatan ekonomi kerakyatan selama ini, kontribusi UMKM dalam perekonomian Indonesia sangat besar, terutama jika dilihat dari aspek-aspek seperti peningkatan kesempatan kerja, sumber pendapatan, pembangunan ekonomi pedesaan, dan peningkatan ekspor non-migas. Jumlah UMKM di Indonesia cukup besar dan bergerak diberbagai sektor ekonomi serta tersebar di seluruh wilayah Indonesia Hal ini dapat dilihat dari data tabel di bawah ini yang menunjukkan perkembangan UMKM di Indonesia pada tahun 2012-2014 cukup berkembang terutama usaha mikro dan usaha kecil.

Tabel 1

Pertumbuhan UMKM di Indonesia Tahun 2012 - 2013

PERKEMBANGAN

TAHUN 2012-

NO INDIKATOR SATUAN TAHUN 2012**) TAHUN $2013 * * *$ ) 2013

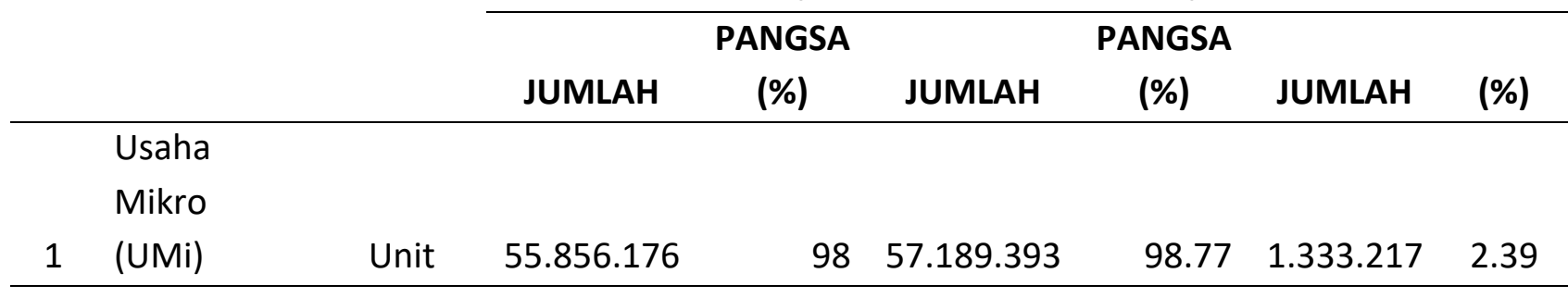

\begin{tabular}{|c|c|c|c|c|c|c|c|c|}
\hline 2 & $\begin{array}{l}\text { Usaha Kecil } \\
\text { (UK) }\end{array}$ & Unit & 629.418 & 1.11 & 654.222 & 1.13 & 24.803 & 3.94 \\
\hline & Usaha & Unit & 48.997 & 0.09 & 52.106 & 0.09 & 3.110 & 6.35 \\
\hline
\end{tabular}




\section{Menengah}

(UM)

\begin{tabular}{|c|c|c|c|c|c|c|c|c|}
\hline & Usaha & & & & & & & \\
\hline 4 & Besar (UB) & Unit & 4.968 & 0.01 & 5.066 & 0.01 & 98 & 1.97 \\
\hline \multicolumn{9}{|c|}{ Keterangan : } \\
\hline \multicolumn{9}{|c|}{ **) Angka Sangat Sementara } \\
\hline \multicolumn{9}{|c|}{$* * *)$ Angka Sangat-Sangat Sementara } \\
\hline & & Sumbe & nterian & rasi d & M (diola & & & \\
\hline
\end{tabular}

Menurut Zulkieflimansah (2003) usaha kecil dan menengah, termasuk industri berskala kecil yang memberikan kontribusi positif terhadap perekonomian suatu negara karena menciptakan lapangan pekerjaan dengan modal yang rendah, mengisi market nice yang tidak efisien bagi perusahaan besar, dan sebagai pool of skill dan semi skill workers. UMKM memiliki keunggulan lain yakni tahan terhadap krisis, sebagai contoh ketika terjadi krisis ekonomi pada tahun 1997/1998 UMKM mempunyai ketahanan dalam menghadapi krisis.

Pentingnya peran UMKM dalam perekonomian Indonesia menjadikan pemerintah ikut berpartisipasi dalam pertumbuhannya. Beberapa upaya pemerintah dalam meningkatkan pertumbuhannya adalah dengan memberikan kemudahan pada perijinan pendirian UMKM dan memberika dana bergulir kepada UMKM. Tidak hanya pemerintah yang berupaya dalam peningkatan pertumbuhan UMKM. Lembaga Keuangan (LK) ikut berperan dalam pertumbuhan UMKM. Salah satu peran LK dalam pertumbuhan UMKM adalah dengan memberikan kredit khusus untuk UMKM.

Di Indonesia Lembaga Keuangan dibagi menjadi dua yakni Lembaga keuangan dengan prinsip ekonomi konvensional dan lembaga keuangan dengan prinsip ekonomi syariah. Perkembangan Lembaga Keuangan Syariah (LKS) di Indonesia cukup baik. Hal ini terlihat pada asset yang terdapat pada lembaga keuangan syariah yakni bank syariah meningkat dari tahun ketahun. Dari pertumbuhan asset pada bank syariah dapat dilihat sebagian asset digunakan untuk pembiayaan UMKM. Hal tersebut memperlihatkan bahwa bank syariah turut berperan serta dalam pertumbuhan UMKM. Berikut adalah data pertumbuhan pembiaayaan pada Bank Umum Syariah (BUS) dan Unit Usaha Syariah (UUS).

Tabel 2

Pembiayaan Pada BUS, BPRS dan UUS Berdasarkan Golongan Pembiayaan

Tahun 2007 - 2013

\begin{tabular}{|c|c|c|c|c|c|c|c|}
\hline & 2007 & 2008 & 2009 & 2010 & 2011 & 2012 & 2013 \\
\hline PEMBIAYAAN & $\begin{array}{c}\text { Desembe } \\
r\end{array}$ & $\begin{array}{c}\text { Desembe } \\
r\end{array}$ & $\begin{array}{c}\text { Desembe } \\
r\end{array}$ & $\begin{array}{c}\text { Desembe } \\
r\end{array}$ & $\begin{array}{c}\text { Desembe } \\
\mathbf{r}\end{array}$ & $\begin{array}{c}\text { Desembe } \\
\mathbf{r}\end{array}$ & $\begin{array}{c}\text { Agustu } \\
\mathrm{s}\end{array}$ \\
\hline Usaha Kecil dan & & & & & & & 104,72 \\
\hline Menengah & 19,566 & 27,063 & 35,799 & 52,570 & 71,810 & 90,860 & 7 \\
\hline
\end{tabular}


Selain Usaha

\section{Lanjutan Tabel 2}

Kecil dan

Menengah

8,379

11,132

11,087

15,611

30,845

56,645

69,810

174,53

Total

27,945

38,195

46,886

68,181

102,655

147,505 7

Sumber: Bank Indonesia: 2013

Bank Syariah dan Unit Usaha Syariah telah menyalurkan dana pembiayaan yang cukup besar pada UMKM, namun hal ini masih dirasa kurang maksimal. Hal tersebut terjadi karena sebagian besar UMKM merupakan masyarakat dengan tingkat pendidikan setara dengan SMA sehingga ckup sulit apabila melakukan transaksi keuangan yang menditail. Disinilah peran BPRS (Bank Permbiayaan Rakyat Syariah) melaksanakan fungsinya. Dengan sistem administrasi yang mudah difahami UMKM lebih mudah menjalankan transaksi keuangan oleh BPRS.

Sesuai dengan Undang - undang perbankan syariah nomor 21 tahun 2008 BPRS adalah bank syariah yang dalam kegiatannya tidak memberikan jasa dalam lalu lintas pembayaran. Dari pengertian tersebut maka BPRS masih memiliki fungsi yang sama dengan bank syariah yakni sebagai lembaga intermediasi keuangan sehingga produk yang terdapat pada BPRS sama dengan produk yang terdapat pada bank syariah. Produk pendanaan yang terdapat pada BPRS adalah tabungan dan deposito dengan akad mudharabah atau wadiah, sedangkan produk pembiayaan yang terdapat pada BPRS adalah pembiayaan modal kerja, investasi dan konsumtif dengan beberapa akad seperti mudharabah, musyarakah, murabahah dan salam. Dengan adanya fungsi yang sama dengan bank syariah namun dalam administrasi lebih mudah dan jangkauan kepada masyakat kecil lebih dekat maka diharapkan adanya fungsi BPRS sebagai lembaga intermediasi keuangan dapat meningkatkan kesejahteraan masyarakat, khususnya bagi UMKM.

Berdasarkan fenomena diatas maka penelitian ini akan membahas mengenai pembiayaan pada BPRS dalam peningkatan kesejahteraan UMKM dengan dasar maqashid syariah. Penilaian kesejahteraan menggunakan dasar maqashid syariah yang terdiri dari agama, akal, jiwa, keturunan dan harta.

\section{LANDASAN TEORI}

\section{Bank Pembiayaan Rakyat Syariah}

Bank Pembiayaan Rakyat (BPR) menurut Undang-undang (UU) perbankan No. 7 tahun 1992 adalah lembaga keuangan bank yang menerima simpanan hanya dalam deposito berjangka, tabungan/bentuk lainnya yang dipersamakan dengan itu dan menyalurkan dana sebagai usaha BPR. Sedangkan UU perbankan No. 10 tahun 1998, disebutkan bahwa BPR adalah lembaga keuangan bank yang melaksanakan kegiatan usahanya secara konvensional atau berdasarkan prinsip syariah. 
Pelaksanaan BPR yang melakukan kegiatan usaha berdasarkan prinsip syariah selanjutnya diatur menurut Surat Keputusan Direktur Bank Indonesia No. 32/36/KEP/DIR/1999 tanggal 12 Mei 1999 tentang BPR Berdasarkan Prinsip Syariah. Dalam hal ini, secara teknis BPR syariah bisa diartikan sebagai lembaga keuangan sebagaimana BPR konvensional, yang operasinya menggunakan prinsip-prinsip syariah (Sudarsono, 2003:83).

Bank Pembiayaan Rakyat Syariah (BPRS) berdasarkan UU No. 7 tahun 1992 tentang perbankan sebagaimana diubah dengan UU No. 10 tahun 1998 adalah bank yang melaksanakan kegiatan usaha berdasarkan prinsip syariah yang dalam kegiatannya tidak memberikan jasa dalam lalu lintas pembayarannya.

Tidak memberikan jasa dalam lalu lintas pembayarannya maksudnya adalah BPRS dilarang menerima simpanan berupa giro dan ikut serta dalam lalu lintas pembayaran, melakukan kegiatan usaha dalam valuta asing, melakukan penyertaan modal, melakukan usaha perasuransian dan melakukan usaha sebagaimana diluar kegiatan yang telah ditetapkan Undang-undang.

Penyaluran pembiayaan kepada pelaku UMKM terbagi menjadi dua katagori yang dibedakan berdasarkan tujuan penggunaanya, yaitu :

1. Transaksi jual beli berdasarkan akad :

a. Murabahah

Murabahah adalah akad jual beli pada harga asal dengan tambahan keuntungan yang disepakati oleh pihak-pihak yang mengadakan akad murabahah (Antonio, 2001 : 101).

Pembiayaan murabahah berasal dari kata ribhu (keuntungan), yaitu transaksi jual beli dimana bank menyebut jumlah keuntungannya. Harga jual adalah harga beli dari pemosok ditambah keuntungan (margin) dan kedua pihak harus menyepakati harga jual dan jangka waktu pembayaran (Karim, 2007 :98).

b. Istishna

Menurut Antonio (2001 : 113) transaksi isthisna' merupakan suatu kontrak perjanjian jual beli anatar pembeli dan pembuat barang. Dalam kontrak ini pembuat barang menerima pesanan dari pembeli, pemuat barang lalu berusaha melalui orang lain untuk membuat atau membeli barang menurut spesifikasi (jenis, macam, ukuran, mutu, dan jumlahnya) yang telah disepakati dan menjualnya kepada pembeli akhir. Kedua belah pihak sepakat atas harga serta system pembayaran dilakukan dimuka, melalui cicilan, atau ditangguhkan sampai pada waktu masa yang akan datang.

c. Salam

Salam adalah transaksi jual beli dimana barang yang diperjual belikan belum ada. Salam berarti pembelian barang yang diserahkan di kemudian hari sementara pembayaran dilakukan di muka. Barang yang diterima harus sesuai karakteristik yang telah disepakati antara pembeli dan penjualbaik itu jenis, macam, kualitas, dan kuantitasnya (Karim, 2009 : 99). 
2. Pembiayaan bagi hasil berdasarkan akad :

a. Mudharabah

Mudharabah adalah kerjasama usaha antara dua belah pihak dimana pihak pertama (Shahibul maal) menyediakan seluruh modal, sedangkan pihak lainnya pengelola (Mudharib). Keuntungan usaha secara mudharabah dibagi menurut kesepakatan yang dituangkan dalam kontrak, sedangkan apabila rugi ditanggung oleh pemilik modal selama kerugian itu diakibatkan bukan akibat kelalaian si pengelola, seandainya kerugian itu diakibatkan karena kecurangan atau kelalaian si pengelola, si pengelola harus bertanggung jawab atas kerugian tersebut (Antonio, 2001, : 95).

b. Musyarakah

Musyarakah adalah akad kerja sama antara dua belah pihak atau lebih untuk suatu usaha tertentu dimana masing-masing pihak memberikan kontribusi dana (amal) dengan kesepakatan bahwa keuntungan dan resiko akan ditanggung bersama sesuai dengan kesepakatan.

Dalam pembiayaan islam pembiayaan mudharabah dapat diterapkan pada usahausaha yang sifatnya resiko rendah misal dengan satu usaha atau kegiatan sesaat sehingga dapat dihitung pendapatan dan keuntungan, sedangkan musyarakah dapat diterapkan untuk usaha-usaha mikro atau sector informal seperti syirkah barang dagangan.

Penerapan pembiayaan mudharabah dan musyarakah untuk pemberdayaan UMKM tidak sekedar transfer dana tetapi dibutuhkan transfer of knowledge, bukan hanya sosialisasi dan promosi, maka diperlukan pula adanya edukasi (Silvia dan Choundhury, 2006).

3. Prinsip Sewa (ljarah)

Transaksi ljarah dilandasi adanya perpindahan manfaat. Jadi pada dasarnya prinsip ljarah sama saja dengan prinsip jual beli, tapi perbedaanya terletak pada objeknya transaksinya. Bila pada jual beli objek transaksinya adalah barang, pada ljarah objek transaksinya adalah jasa. Menurut Antonio (2001:117) ljrah adalah akad pemindahan hak guna atas barang atau jasa, melalui pembayaran upah sewa, tanpa diikuti dengan pemindahan kepemilikan atas barang itu sendiri. Namun pada masa akhir sewa lembaga keuangan syariah dapat menjual barang yang disewkannya kepada nasabah. Karena itu dikenal adanya ljarah muntahhiyah bittamlik (sewa yang diikiti dengan berpindahnya kepemilikan).

\section{Kesejahteraan Usaha Dalam Perspektif Islam}

Menurut Anto (2003: 74) dan PEI (2008: 53) menyatakan bahwa kesejahteraan dalam Islam terbagi menjadi dua, yaitu : 
Kesejahteraan Holistic yang seimbang, yaitu mencakup dimensi material maupun spiritual serta mencakup individu maupun social. Manusia akan merasa bahagia jika terdapat keseimbangan antara dirinya dan lingkungan sosialnya.

Kesejahteraan di dunia maupun di akhirat, sebab manusia tidak hanya hidup di dunia saja tetapi juga di akherat kelak. Jika kondisi ideal ini bisa dicapai maka kesejahteraan di akherat tentu lebih diutamakan, karena kehidupan akherat yang abadi dan bernilai daripada kehidupan dunia.

Menurut Imam Al-Ghazali dalam Euis (2005 : 123) menyatakan bahwa maslahah (kesejahteraan) adalah memelihara tujuan syariah yang terletak pada :

1. Perlindungan agama (ad-din)

2. Perlindungan Jiwa (an-nafs)

3. Perlindungan Akal (al-'aql)

4. Perlindugan Keturunan/Kehormatan (an-nasl)

5. Perlindungan Harta (al-maal)

Al-Syatibi dalam Karim (2004 : 381) menyatakan bahwa sesungguhnya syariah bertujuan untuk mewujudkan kemaslahatan manusia di dunia dan akhirat. Hal ini sesuai dalam tuntuan wahyu, bahwa tujuan kehidupan manusia adalah untuk mencapai kebahagiaan dunia dan akhirat. Maksud dari tujuan kemaslahatan ini adalah yang menyangkut dengan kebutuhan, baik kebutuhan ekonomi maupun sosial.

\section{Penelitian Terdahulu}

Herianingrum (2013) dalam penelitiannya yang berjudul "Pengaruh Pembiayaan Bank Syariah terhadap Kinerja Usaha dan Kesejahteraan Pengusaha Kecil Tijarah Zira'ah di Jawa Timur". Salah satu hasil penelitiannya adalah Pembiayaan bank syariah berpengaruh signifikan dengan arah posistif terhadap kesejahteraan, sehingga apabila pembiayaan bank syariah meningkat makan akan meningkatkan kesejahteraan.

\section{METODE PENELITIAN}

Pendekatan yang digunakan dalam penelitian ini adalah pendekatan kualitatif deskriptif. Data yang digunakan adalah data primer dengan tekhnik wawancara. Teknik wawancara dilaksanakan karena dengan teknik wawancara peneliti dapat lebih luwes dalam mengambil informasi sehingga hasil yang akan lebih focus dan mendalam. Sedangkan sampel peneltian adalah Bank Pembiayaan Syariah (BPRS) Sarana Prima Mandiri Pamekasan dan nasabah UMKM pada BPRS Prima Mandiri Pamekasan. Pamekasan dipilih karena terdapat potensi yang besar pada UMKM, namun masih harus ada pembenahan dalam menggali potensi tersebut.

Responden dalam penelitian ini adalah berjumlah 40 orang yang mendapatkan pembiayaan di BPRS Sarana Prima Mandiri Pamekasan. 
Tabel 3

Karakteristik Nasabah UMKM BPRS Prima Mandiri Pamekasan

\begin{tabular}{|c|l|l|r|r|}
\hline NO & ASPEK & URAIAN & JUMLAH (ORANG) & PROSENTASE \\
\hline 1 & Jenis Kelamin & Pria & 38 & $95 \%$ \\
\hline & & Wanita & 2 & $5 \%$ \\
\hline 2 & Usia & $<25$ Th & 0 & $0 \%$ \\
\hline & & $25-30$ Th & 2 & $5 \%$ \\
\hline & & $31-40$ Th & 10 & $25 \%$ \\
\hline & & $41-50$ Th & 20 & $50 \%$ \\
\hline & & $>50$ Th & 8 & $20 \%$ \\
\hline 3 & Status Perkawinan & Kawin & 1 & $98 \%$ \\
\hline & & Tidak Kawin & 15 & $3 \%$ \\
\hline 4 & Pendidikan Trekahir & SD & 8 & $20 \%$ \\
\hline & & SMP & 16 & $40 \%$ \\
\hline & & SMA & 0 & $0 \%$ \\
\hline & & DIII & 1 & $3 \%$ \\
\hline & & S1 & & $38 \%$ \\
\hline
\end{tabular}

Sumber : Hasil olah data BPRS Prima Mandiri Pamekasan

Berdasarkan hasil olah data di dapat sebagian besar yakni 95\% jenis kelamin nasabah pembiayaan adalah pria dan sisanya sebesar $5 \%$ adalah wanita. Nasabah UMKM sebagian besar merupakan individu dengan usia produktif yakni $25-50$ tahun. Akan tetapi seperti yang dapat dilihat dari tabel diatas tingkat pendidikan sebagian besar nasabah UMKM merupakan lulusan SMA. Hal ini terjadi karena BPRS merupakan lembaga keuangan syariah dengan fokus pada pengembangan UMKM dan masyarakat menengah kebawah dengan berbagai kemudahan baik dalam segi administrasi, besaran pembiayaan dan prosedur pembiayaan. Diharapkan dengan adanya BPRS di setiap pelosok Indonesia dapat memfasilitasi kebutuhan pembiayaan bagi UMKM dan semua tingkatan masyarakat.

BPRS Prima Mandiri Pamekasan memiliki nasabah UMKM yang cukup beragam karakteristiknya. Namun sebagian besar usaha nasabah BPRS berada di wilayah Kabupaten Pamekasan. Berikut merupakan kriteria usaha nasabah UMKM BPRS Prima Mandiri Pamekasan

Tabel 4.

Kriteria Usaha Nasabah UMKM BPRS Prima Mandiri Pamekasan

\begin{tabular}{|r|l|l|r|r|}
\hline NO & ASPEK & URAIAN & JUMLAH (UNIT) & PERSENTASE \\
\hline 1 & Modal Tahun Pertama & $<10 \mathrm{jt}$ & 14 & $35 \%$ \\
\hline & & $10-50 \mathrm{Jt}$ & 23 & $58 \%$ \\
\hline & & $>50 \mathrm{jt}$ & 3 & $8 \%$ \\
\hline 2 & Jumlah Pekerja & Tidak ada & 22 & $55 \%$ \\
\hline & & $<5$ Orang & 17 & $43 \%$ \\
\hline & & $5-10$ Orang & 1 & $3 \%$ \\
\hline & & $>10$ & 0 & $0 \%$ \\
\hline 3 & Periode Usaha & $<3 \mathrm{Th}$ & 4 & $10 \%$ \\
\hline & & $3-5 \mathrm{Th}$ & 4 & $10 \%$ \\
\hline & & $>5 \mathrm{Th}$ & 32 & $80 \%$ \\
\hline 4 & Periode Bermitra dengan Bank Syariah & $<2$ Th & 26 & $65 \%$ \\
\hline & & $>2 \mathrm{Th}$ & 14 & $35 \%$ \\
\hline
\end{tabular}

Sumber : Hasil olah data BPRS Prima Mandiri Pamekasan 
Sebagian besar nasabah sebanyak 58\% dengan jumlah 23 unit UMKM membutuhkan modal di tahun pertama sebesar 10 - 50 juta, sebesar 35\% dengan jumlah 14 unit UMKM membutuhkan modal kurang dari 10 juta dan sebesar $8 \%$ dengan jumlah 3 unit UMKM membutuhkan modal lebih dari 50 juta. Bila di analisis dari jumlah pekerja yang dipekerjakan pada UMKM sebagian besar sebanyak 43\% atau 22 UMKM mengelola usahanya sendiri, 43\% yakni 17 UMKM memiliki pekerja kurang dari 5 orang dan sebesar 3\% yakni 1 UMKM memiliki pekerja 5 - 10 orang. Dilihat dari periode usaha sekitar $80 \%$ yakni 32 UMKM memiliki periode usaha yang cukup lama diatas 5 tahun dan masing masing sebesar 10\% dengan jumlah 4 UMKM memiliki periode usaha di bawah 3 tahun dan periode usaha antara $3-5$ tahun. Terakir bila di lihat dari kemitraan bersama BPRS, sebagian besar 26\% atau 26 UMKM kurang dari 2 tahun bermitra dengan BPRS dan sisanya 35\% atau 14 orang lebih dari 2 tahun bermitra dengan BPRS.

\section{ANALISA DAN DISKUSI}

\section{Kinerja Usaha}

Keberhasilan penyaluran pembiayaan kepada UMKM dapat dilihat dari kinerja usaha yang berhasil dicapai oleh UMKM dalam mengelola dana pembiayaan yang telah didapatkannya. Keberhasilan tersebut dapat diukur dari indikator antara lain laba usaha dan asset usaha.

1. Laba Usaha

Setelah mendapatkan pembiayaan dari BPRS, UMKM menyatakan mengelola dana pembiayaan tersebut dengan dibantu istri dan anaknya. Mereka melakukan pencatatan dengan tertib dan dilakukan dengan lebih professional.

Jadi setelah mendapatkan pembiayaan dari BPRS, UMKM menjadi lebih bersemangat dalam menjalankan usahanya, bukti keberhasilan ini adalah hasil penjualan yang meningkat, sehingga pendapatannya juga ikut meningkat, laba usaha meningkat, dan mampu melakukan ekpansi usaha.

\section{Aset Usaha}

Para pelaku UMKM menyatakan bahwa setelah medapatkan pembiayaan dari BPRS, usaha mereka rata-rata mengalami peningkatan antara lain bisa ekpansi usaha, inovasi, serta dapat mengajak saudara dan teman untuk mengembangkan usaha, hal ini berbanding lurus dengan jumlah penjualannya semakin meningkat, sehingga laba yang dihasilkan juga ikut meningkat, dan akhirnya dapat meningkatkan asset usaha.

Dengan meningkatnya laba UMKM dapat menambah asset seperti took yang semakin besar, barang dagangan yang semakin meningkat, bisa membeli ternak, bahkan bisa membeli kendaraan dan sawah.

Berdasarkan dari hasil wawancara yang dilakukan kepada nasabah pembiayaan UMKM BPRS Prima Mandiri Pamekasan, tekait hubungan pembiayaan dengan kesejahteraan nasabah UMKM dengan indikator maqashid syariah didapat hasil sebagai berikut:

1. Perlindungan agama (ad-din) 
Sebagai bentuk peelindungan agama maka Allah memerintahkan kepada hambanya untuk melaksanakan ibdah seperti shalat, zakat, puasa, infaq, shadaqah dan lain sebagainya. Perlindungan agama dibagi menurut tingkat kebutuhannya seperti daruriyat, hajiyyat dan tahsiniyat. Perlindungan agama pada tingkat daruriyyat meliputi melaksanakan shalat lima waktu, zakat, puasa dan lain sebagainya. Perlindungan agama pada tingkat hajiyat yaitu melaksanakan ketentuan agama dengan maksud menghindari kesulitan seperti menjama' atau mengqasar shalat. Perlindungan agama pada tingkat tahsiniyat adalah mengikuti petunjuk agama demi menjunjung tinggi martabat manusia seperti menutup aurat.

Perlindungan agama yang dianalisis merupakan perlindungan agama pada lingkup daruriyyat. Sebagian besar nasabah pembiayaan mengalami peningkatan kesejahteraan setelah mendapatkan pembiayaan dari BPRS. Zakat, infaq, dan sodaqoh relatif meningkat. Adanya pembiayaan dari BPRS kepada nasabah UMKM, nasabah UMKM merasa terbantu karena kesulitan utama adalah permodalan sehingga setalah masalah permodalan teratasi, maka hasil usaha UMKM semakin meningkat, sehingga secara otomatis pendapatan ikut meingkat. Dengan adanya pendapatan ini UMKM dapat berbagi kepada sesama melalui peningkatan zakat, Infaq, dan sodaqoh.

\section{Perlindungan Jiwa (an-nafs)}

Islam merupakan agama yang melindungi keselamatan jiwa manusia, sehingga segala sesuatu yang merusak atau menganggu jiwa tidak diperbolehkan dalam islam. Sama halnya dengan perlindungan agama, dalam perlindungan jiwa dibagi menjadi tiga yakni daruriyat, hajiyayat dan tahsiniyat. Pada perlindungan daruriyat dicontohkan adalah manusia dapat mencukupi kebutuhan pokok hidupnya seperti dengan mengkonsumsi makanan. Sedangkat perlindungan jiwa pada hajiniyat yakni setiap manusia dapat mengkonsumsi makanan yang halal dan lezat. Terakir perlindungan jiwa tahsiniyyat adalah dimana terhadapat hubungan antara etika berkonsumsi dengan konsumsi individu.

Seperti halnya dengan perlindungan agama, batasan pada analisis hanya pada perlindungan jiwa secara daruriyat. Setelah mendapatkan pembiayaan dari BPRS pengeluarn belanja khususnya kebutuhan konsumsi UMKM lebih tercukupi. Sebelum mendapatkan pembiayaan dari BPRS, nasabah UMKM jarang mengkonsumsi makanan mewah seperti daging. Namun setelah mendapatkan pembiayaan dari BPRS dan mengalami peningkatan hasil usaha nasabah UMKM dapat lebih sering mengkonsumsi makanan mewah seperti daging. Perlindungan jiwa tidak hanya pada konsumsi, dengan peningkatan hasil usaha nasabah UMKM dapat mengikuti asuransi BPJS.

\section{Perlindungan Akal (al-'aql)}

Islam mewajibkan untuk setiap manusia menjaga akalnya. Manusia diperintahkan untuk tidak meminum khamar, mengkonsumsi narkoba dan sebagainya yang dapat merusak akal. Di sisi lain manusia diwajibkan untuk terus menuntut ilmu untuk mengembangkan akalnya. Perlindungan akal dibedakan menjadi tiga, daruriyyat, hajiniyat dan tahsiniyat. Pada konteks daruriyyat, islam mengharamkan manusia untuk mengkonsumsi khamar, narkoba dan hal - hal yang merusak akal. Pada konteks hajiniyyat, islam menganjurkan untuk setiap individu mendapatkan pendidikan yang layak. Sedangkan pada konteks 
tahsiniyyat yakni manusia lebih baik menerima hal - hal yang bermanfaat bagi hidupnya dan meninggalkan yang buruk

Dari hasil wawancara, selama ini pengeluaran sebagian besar digunakan untuk pembelian peralatan usaha atau kebutuhan usaha. Sedangkan untuk seminar atau pelatihan sangat jarang. Sebagian besar nasabah UMKM melaksanakan pelatihan di dinas koperasi dan UMKM.

4. Perlindugan Keturunan/Kehormatan (an-nasl)

Agar dapat melindungi keturunan, syariat islam menganjurkan untuk menikah dan mengharamkan perbuatan zina. Perlindungan keturunan dibagi menjadi daruriyyat, hajiniyat dan tahsiniyyat. Pada daruriyat, islam menganjurkan untuk menikah dan tidak berbuat zina. Pada tingkatan hajiniyyat, ditetapkannya penyebutan mahar bagi suami pada saat akad nikah. Sedangkan pada tingkatan tahsiniyyat adalah adanya khitbah dalam pernikahan.

Perlindungan keturunan tidak hanya dalam konteks pernikahan namun dapat juga dalam konteks bagaimana suatu keluarga dapat memberikan hal yang baik dan positif untuk keturunannya seperti pendidikan, warisan, asuransi kesehatan dan lain sebagainya. Setelah mendapatkan pembiayaan, sebagian besar nasabah UMKM memiliki peningkatan kemampuan belanja untuk masa depan, khususnya untuk anak. Nasabah UMKM dapat membelikan penunjang kebutuhan sekolah anak dengan kuantitas dan kualitas yang lebih baik dari sebelumnya.

5. Perlindungan Harta (al-maal)

Islam menganjurkan setiap umatnya memperoleh harta yang halal dengan berbagai macam cara bermuamalah seperti jual beli, sewa menyewa, perkongsian, gadai dan sebagainya. Islam melarang umatnya untuk memakan harta yang batil seperti mencuri, riba, gharar dan lain sebagainya. Perlindungan harta juga terbagi menjadi tiga yakni daruriyat, hajiniyyat dan tahsiniyyat.

Seluruh nasabah UMKM telah dapat melakukan perlindungan pada harta dengan bermuamalah menggunakan produk syariah BPRS Prima Mandiri Pamekasan. Dari hasil muamalah tersebut, sebagaian besar nasabah UMKM menghasilkan pendapatan yang meningkat dari hasil usahanya. Peningkatan pendapatan hasil usaha dapat digunakan oleh nasabah UMKM untuk mengembangkan hasil usahanya.

\section{SIMPULAN}

Berdasarkan hasil analisis yang dilakukan kepada nasabah pembiayaan BPRS Prima Mandiri Pamekasan, didapat hasil bahwa terdapat keterkaitan antara pembiayaan dengan kesejahteraan nasabah BPRS. Hal ini di mungkinkan karena ketika nasabah mendapatkan pembiayaan maka hasil usaha akan meningkat. Ketika hasil usaha meningkat maka secara otomatis nasabah dapat meningkatkan kesejahteraan. Peningkatan kesejahteraan dapat diukur dengan maqashid syariah, seperti meningkatnya zakat, infaq, shadaqah nasabah, meningkatnya pemenuhan konsumsi sehari - hari nasabah, terpenuhinya kebutuhan untuk 
pendidikan, meningkatnya investasi masa depan dan nasabah dapat mengembangkan usahanya.

Dengan meningkatnya kesejahteraan nasabah maka dapat dikatakan BPRS Prima Mandiri Pamekasan memiliki peranan yang penting khususnya dalam penyediaan modal. Akan tetapi hendaknya BPRS juga memberikan penyuluhan atau sosialisasi untuk nasabah, baik pelatihan dalam meningkatkan keterampilan, mengatur keuangan, sosiologi agama, sehingga nasabah dapat menjadi lebih baik.

\section{DAFTAR PUSTAKA}

1993. Al-Qur'an dan Terjemahannya. Bandung. C.V Gema Risalah Press.

2015. Perkembangan Data Usaha Mikro Kecil dan Menengah (UMKM) dan Usaha Besar (UB) tahun 2012-2013. (on line), (www.depkop.go.id, diakses 16 November 2015)

2015. Koran Kabar Pamekasan. (on line), (www.google.com, diakses 17 November 2015)

Adi, M Kwartono. 2007. Analisis Usaha Kecil dan Menengah.Yogyakarta. C.V ANDI OFFSET.

Amalia, Euis. 2009. Keadilan distributif dalam Ekonomi Islam Penguatan Peran LKM dan UKM di Indonesia. Jakarta. PT. RajaGrafindo Persada.

Antonio, Muhammad Syafi'I. 2001. Bank Syariah dari Teori Ke Praktek. Jakarta. Gema Insani Press.

Karim, Adiwarman, 2007. Bank Islam, Raja Grafindo Persada, Jakarta

Kuncoro, 2008. Pembiayaan Usaha Kecil. Economic Review, no.211 (3) : 1-10.

Muhammad. 2000. Lembaga-lembaga Keuangan Umat Kontemporer. Yogyakarta. UII. Press.

Silvia, Bayu and Choundhury, Masadul Alam, A Phenomenological Conception of Private Sector Responsibility in Social Economics, Vol 33, No 12, 2006pp 796-807

Sudarsono, Heri. 2003. Bank dan Lembaga Keuangan Syariah: Deskripsi dan Ilustrasi. Yogyakarta. Ekonosia. 